\title{
Peran Pembiayaan Murabahah Dalam Meningkatkan Usaha Batu Bata (Studi Pada BMT As-Salam Kantor Kas Ngereco Kandat Kediri)
}

\author{
*1 Muh. Khoirul Anam, ${ }^{2}$ Haris Santoso \\ ${ }^{1}$ STAINU Malang, ${ }^{2}$ IAIM NU Metro Lampung \\ e-mail: *1anam123141@gmail.com, ${ }^{2}$ kangharis30@gmail.com
}

\begin{abstract}
Financial institutions are currently needed by all people because financial institutions are considered to be quicker in providing business capital loans. Previously, conventional banks were the only financial institutions operating in the financial sector or loans to the community before Islamic financial institutions, now with the development of financial institutions sharia society mostly prefers sharia finance rather than conventional, plus BMT which operates in the middle to lower class, this is what causes many people to take Islamic financial institutions because they prioritize family systems. Research on the role of murabahah financing in brick business uses a descriptive qualitative approach with a type of case study research that refers to the interpretive postpositivistic thinking paradigm. The technique of collecting data is in-depth interviews, observation and documentation. The results of this study indicate that the application of murabahah financing at BMT As-Salam is very different where loans for business capital of bricks that should use mudharabah or musyarakah at BMT These salads use murabaha. Besides that the role of BMT As-Salam is very influential on brick business and before BMT As-Salam arrived, brick entrepreneurs still had difficulty finding capital to improve their business but after taking murabahah financing at BMT As-Salam, their efforts experienced an increase and prosperity life.
\end{abstract}

Key Words: Murabahah, Brick Business, BMT As-Salam

\section{Abstrak}

Institusi keuangan adalah hal yang paling dibutuhkan di dunia bisnis untuk membantu pembiayaan modal. BMT As-Salam merupakan salah Lembaga keuangan mikro berbasis syariah di Ngereco Ngandat Kediri. Salah satu produk yang banyak dimintai anggota BMT adalah produk Murabahah untuk membantu meningkatkan usaha yang dijalani. Penelitian ini dalah penelitian kualitatif, Teknik penumpulan data dalam penelitian ini dengan wawancara lebih dalam kepada informan, observasi dan dokumentasi. Hasil dari penelitian ini menunjukkan bahwa meningkatkan usaha khusunya di bisnis batu bata.

Key Words: Murabahah, Bisnis Batu Bata, BMT As-Salam

Website:http://jurnal.radenfatah.ac.id/index.php/ieconomics 


\section{PENDAHULUAN}

Secara umum, kebutuhan yang harus dipenuhi manusia dari waktu ke waktu memang sama, yaitu kebutuhan primer, sekunder dan tersier. Apabila kebutuhan primer (pokok) telah terpenuhi, maka seseorang akan berusaha untuk memenuhi kebutuhan sekunder. Kebutuhan sekunder adalah kebutuhan tambahan, yang secara kuantitatif maupun kualitatif lebih tinggi atau lebih mewah dari kebutuhan primer, baik berupa barang seperti makanan, minuman, pakaian atau perhiasan, bangunan rumah, kendaraan. Maupun berupa jasa, seperti pendidikan, pelayanan kesehatan, pariwisata, hiburan, dan sebagainya. ${ }^{1}$ Oleh karena itu, untuk memenuhi semua kebutuhan sekunder, seseorang dituntut untuk mempunyai penghasilan yang mencukupi seluruh pengeluarannya.

Salah satu upaya yang telah dilakukan oleh masyarakat untuk mempunyai penghasilan adalah menjadi wiraswasta atau wirausaha (mempunyai perusahaan pribadi), seorang wirausaha dapat memberikan peran dalam pertumbuhan ekonomi tidak hanya meningkatkan output dan pendapatan perkapita tetapi juga melibatkan pengenalan atau penerapan struktur bisnis maupun masyarakat. ${ }^{2}$ Wiraswasta merupakan alternatif yang efektif untuk memeratakan pendapatan ke semua lapisan masyarakat untuk memenuhi kebutuhan-kebutuhan hidup. Selain itu, M. Umer Chapra menyatakan bahwa wiraswasta dapat memberikan beberapa manfaat kepada negara. Pertama, wiraswasta dapat mencegah urbanisasi karena masyarakat tidak perlu pergi ke kota untuk mencari pekerjaan. Kedua, wiraswasta dapat mencegah pemusatan harta kekayaan pada golongan tertentu. Ketiga, wiraswasta dapat meningkatkan efisiensi dalam perekonomian karena adanya kompetisi menjalankan usaha. ${ }^{3}$

Untuk menjadi wiraswasta yang komplit dan berkembang dibutuhkan faktor pendukung dalam pengembangan usaha ataupun industri, diantaranya:

1) Sumber daya manusia (SDM)

\footnotetext{
${ }^{1}$ Muhammad Syafi'i Antonio, Bank Syari'ah: Dari Teori Ke Praktek (Jakarta: Gema Insani Press, 2001), 168 .

${ }^{2}$ Franky S, Hetty K Tunjungsari, Mei Le, Dasar-Dasar Kewirausahaan:Teori dan Praktik, Jakarta Barat: Indeks, 2016, hal. 2

3 M. Umer Chapra, Towards a just monetary system Bibliolografi, terj Lukman Hakim (Yogyakarta: Dhana Bhakti Prima Yasa, 1997), 44.
}

Website:http://jurnal.radenfatah.ac.id/index.php/ieconomics 
SDM ini sangat dibutuhkan untuk perkembangan usaha, untuk memperoleh hasil maksimal diperlukan SDM yang unggul berpotensi untuk memajukan usahanya, maka dari itu SDM sangat penting.

2) Investasi

Perkembangan investasi sangatlah penting bagi suatu usaha, apalagi usahanya sangat besar, hal ini akan memerlukan banyak investor baik dalam negeri maupun luar negeri, mengacu hal tersebut pada masa mendatang, iklim investasi diharapkan akan semakin kondusif selaras makin meredanya kondisi krisis yang terjadi pada suatu negeri agar investasi bisa mendorong peningkatan usaha.

3) Teknologi

Perkembangan teknologi proses industri sekarang mengalami berbagai kemajuan mendasar terutama karena terus di lakukan kegiatan riset dan pengembangan oleh pemilik proses. Perubahan yang di lakukan antara lain dengan penggunaan bahan baku yang sama, meningkatkan efisiensi bahan baku serta kualitas produk yang di hasilkan.

4) Prasarana, sarana dan utilitas

Ketersediaan infrastruktur bagi suatu usaha adalah peran yang sangat strategis yang memungkinkan meningkatnya suatu usaha. Selain itu selain sarana dan prasarana sudah tersedia diharapkan dapat menekan biaya investasi dan biaya operasional suatu usaha. ${ }^{4}$

Keempat faktor diatas bagi seorang wirasawasta kalangan menegah kebawah akan sangat sulituntuk memenuhinya, untuk itu peran lembaga keuangan sebagai penyedia modal dan juga SDM yang cukup bisa membantu kreatifitas wirasawasta kalangan bawah untuk meningkatkan usahanya. Banyak wiraswasta menengah ke bawah mengalami kesulitan pembiayaan dalam menjalankan operasionalnya, seperti pada masyarakat Ngreco Kandat Kediri yang mayoritas mereka berpenghasilan dari usaha batu bata, dimana dalam menjalankan usahanya mereka sangat butuh modal terlebih dahulu. Dalam hal ini peran lembaga

\footnotetext{
${ }^{4}$ Tim penyusun, Pengembangan industri petrokimia di Indonesia, Jakarta: Indonesia chemichal industries club, 2001, hal : 15-23

Website:http://jurnal.radenfatah.ac.id/index.php/ieconomics
} 
keuangan sangat diharapkan bisa memberi warna bagi wiraswasta kalangan menengah kebawah, dikarenakan tidak mungkin pemerintah memberikan dana APBN atau bantuan langsung dari pemerintah kepada para wiraswasta dikalangan bawah,disamping itu pertumbuhan lembaga keuangan di Indonesia sangat pesat, seiring pemahaman masyarakat tentang Bunga dan modal yang dibayar di awal merupakan bentuk riba yang sangat dilarang dalam Islam, hal itu menimbulkan keraguan pada masyarakat untuk mencari lembaga yang memberikan pelayanan pembiayaan berdasarkan syariat Islam ${ }^{5}$.

Untuk itu peran seperti BMT sangat diharapkan menjadi solusi atau perantara atas kesulitan pembiayaan bagi wiraswasta kalangan bawah. Seperti pada BMT As-salam Kras Kediri yang mulai mendirikan kantor cabang di desa Ngreco Kandat Kediri, yang bertujuan untuk mensejahterakan masyarakat desa Ngreco yang mayoritas pengusaha batu bata dengan memberikan bantuan pembiayaan terhadap usahanya. Dengan pembiayaan murabahah yang disalurkan kepada para pengusaha batu bata tersebut tanpa mengurangi prinsip-prinsip syariat dalam bertransaksi. Karena BMT As-salam Kras Kediri ini memiliki motto sendiri dalam menjalankan usaha mereka yaitu tertuang dalam surat Al-Maidah ayat 2 yang berbunyi :
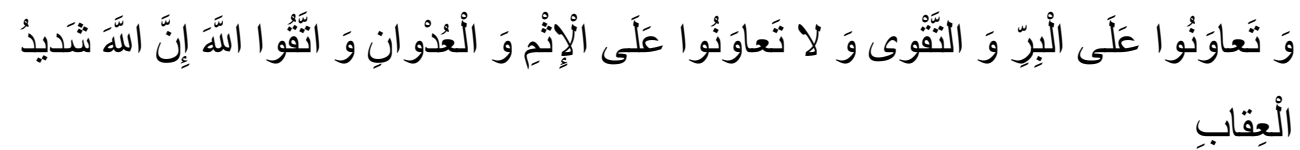

Artinya:

Dan tolong- menolonglah kamu dalam (mengerjakan) kebaikan dan takwa, dan jangan tolong- menolong dalam berbuat dosa dan pelanggaran. Dan bertakwalah kamu kepada Allah, sesungguhnya Allah amat berat siksa-Nya.(Qs. Al-Maidah : 2) ${ }^{6}$

Menurut Heri Sudarsono, Baitul MaalWa Tamwil (BMT) adalah lembaga keuangan pendukung kegiatan ekonomi masyarakat kecil berlandaskan syari'ah

5 Bagya Agung Prabowo, Konsep Akad murabahah pada perbankan syariah(analisa kritis terhadap konsep Akad Murabahah di Indonesia dan Malaysia), Jurnal Hukum No. 1, Vol. 16 Januari, 2009 : 106-126

${ }^{6}$ Departemen Agama RI, AL-Quran dan Terjemahnya AL-Jumanatul 'Ali, Bandung: CV Penerbit J-ART, 2004,Hal. 106

Website:http://jurnal.radenfatah.ac.id/index.php/ieconomics 
islam melalui usaha pengumpulan dan penyaluran dana komersial, dan usaha pengumpulan dan penyaluran dana non profit, seperti zakat, infaq dan shodaqoh. ${ }^{7}$ Selain itu dalam BMT juga memberikan produk-produk yang bisa diakses masyarakat untuk mempermudah dalam memperoleh pembiayaan seperti mudharabah, musyarakah, murabahah, dan qordul hasan. Adapun musyarakah dan mudharabah adalah akad kerjasama antara bank dan pihak nasabah dengan persentase yang telah disepakati bersama, dan keduanya juga sepakat atas keuntungan dan kerugian yang terjadi selama kerja sama. ${ }^{8}$ akad musyarakah dan mudharabah sangat pas apabila digunakan untuk kegiatan usaha, beda dengan murabahah yang khusus untuk akad jual beli ataupun akad qardhul hasan yang mana hanya diperuntukkan kepada nasabah yang sudah loyal kepada BMT atau diperuntukkan kepada nasabah yang benar-benar mengalami kebangkrutan.

Murabahah yaitu pembiayaan suatu barang dengan menegaskan harga belinya kepada pembeli dan pembeli membayarnya dengan harga yang lebih sebagai keuntungan yang disepakati. Murabahah berasal dari kata Ribhu (keuntungan) karena dalam transaksi jual beli bank menyebut jumlah keuntungannya ( margin/mark up $)^{9}$

Akad murabahah merupakan salah satu konsep Islam dalam melakukan perjanjian jual beli, harga dan keuntungan harus disebutkan begitu pula sistem pembayarannya, semua ini dinyatakan di depan sebelum akad resmi (ijab qabul) dinyatakan tertulis. ${ }^{10}$ Konsep ini telah banyak digunakan oleh bank-bank dan lembaga keuangan Islam termasuk BMT untuk pembiayaan modal kerja dan pembiayaan perdagangan para nasabahnya. pembayarannya dalam tiap bulan hanya keuntungannya saja dan pada saat jatuh tempo (panen) baru pembiayaan pokok beserta keuntungan sesuai dengan kesepakatan bersama, misalnya: petani membutuhkan modal, sedangkan panen belum tiba, maka petani tersebut dapat

\footnotetext{
${ }^{7}$ Heri Sudarsono, Bank dan Lembaga Keuangan Syari'ah, Deskrips dan Ilustrasi (Yogyakarta: Ekonisia, 2003) hal. 84.

${ }^{8}$ Muhammad, Sistem dan Prosedur Operasional Bank Syariah, Yogyakarta: UII Press Yogyakarta,2008, hal.9

${ }^{9}$ Andri Soemitra, Bank dan Lembaga Keuangan Syariah, Jakarta: Kencana, 2016. Hal. 74

${ }^{10}$ Tim Esistensi, Pengembangan Lembaga Keuangan Syari'ah Bank Muamalat, Perbankan Syari'ah Perspektif Praktisi Muamalat Institut, 1992, 40.
}

Website:http://jurnal.radenfatah.ac.id/index.php/ieconomics 
meminta kepada BMT atau lembaga keuangan syari'ah untuk membiayai kebutuhan operasionalnya, cara pembayarannya tiap bulan hanya cicilan keuntungan saja dan pada masa panen atau akhir pembayaran pokok dan keuntungan, adapun keuntungan BMT sesuai kesepakatan. ${ }^{11}$

Seperti yang telah disinggung diatas, praktek pembiayaan murabahah dalam pembiayaan wirausaha ini sudah dilakukan di BMT As-salam cabang Ngreco Kandat Kediri, yaitu pada usaha batu bata di desa Ngreco Kandat Kediri, Berdasarkan fenomena dan celah yang telah di paparkan sebelumnya dirasa ada gap dalam pengaplikasian produk murabahah dan akad kepada kebutuhan yang bersifat usaha. maka pertanyaan penelitiannya adalah Bagaimana penerapan pembiayaan murabahah di BMT As-salam cabang Ngreco Kandat Kediri terhadap usaha batu bata di desa Ngreco Kandat Kediri? Bagaimana peranan pembiayaan murabahah di BMT As-salam cabang Ngreco Kandat Kediri terhadap peningkatan usaha batu bata di desa Ngreco Kandat Kediri? Bagaimana peningkatan usaha batu bata di desa Ngreco Kandat Kediri setelah mendapatkan pembiayaan murabahah di BMT As-salam cabang Ngreco Kandat Kediri?

Dengan demikian tujuan penelitian adalah untuk mendeskripsikan dan menganalisis penerapan dan peranan pembiayaan murabahah di BMT As-salam cabang Ngreco Kandat Kediri terhadap usaha batu bata di desa Ngreco Kandat Kediri dan untuk menganalisis peningkatan usaha batu bata di desa Ngreco Kandat Kediri setelah mendapatkan pembiayaan murabahah di BMT As-salam cabang Ngreco Kandat Kediri.

\section{METODOLOGI PENELITIAN}

Penelitian tentang peranan pembiayaan murabahah di BMT As-salam cabang Ngreco Kandat Kediri pada usaha batu bata di Desa Ngreco Kandat Kediri ini menggunakan pendekatan kualitatif deskriptif dengan jenis penelitian studi kasus yang mengacu pada paradigma berfikir postpositivistik Interpretatif. Teknik pengumpulan data dengan wawancara mendalam, observasi dan dokumentasi.

\footnotetext{
${ }^{11}$ Muhammad, Sistem dan Prosedur Operasional Bank Syariah.hal.22

Website:http://jurnal.radenfatah.ac.id/index.php/ieconomics
} 


\section{HASIL DAN PEMBAHASAN}

\section{A. Penerapan Pembiayaan murabahah di BMT As-salam cabang Ngreco Kandat Kediri terhadap usaha batu bata di desa Ngreco}

1. Mekanisme Pembiayaan Murabahah di BMT As-Salam

Debitur (pengusaha batu bata) adalah seorang yang berhutang pada orang lain (BMT As-salam). Keterangan di atas pada awalnya Debitur datang kepada lembaga keuangan dan mengajukan permohonan pembiayaan, disini akan terjadi tawar menawar awal antara Debitur dan BMT Assalam, setelah dirasa cukup dan saling sepakat maka Debitur mengisi formulir pendaftaran sebagai anggota baru atau sebagai pendaftaran pembiayaan, kemudian pihak BMT As-salam akan melakukan survey kepada nasabah (pengusaha batu bata). Misalnya datang kerumah atau bertanya kepada tetangga dan melihat kondisi nasabah (pengusaha batu bata), lalu pihak BMT As-salam akan melakukan apakah tepat dalam memberikan pembiayaan kepada calon nasabah (pengusaha batu bata), setelah dirasa cukup maka BMT As-salam akan memberikan keputusan tentang pemberian pembiayaan, lalu terjadi pengikatan akad yang digunakan, dalam hal ini pihak BMT As-salam akan menjelaskan bagaimana prosedur yang akan digunakan untuk ansuran ataupun yang lain, terutama lembaga yang syariah penjelasan tentang akad sangatlah penting karena bersangkutan dengan syarat - syarat sistem syariah. Kemudian BMT As-salam akan merealisasikan pembiayaan tersebut, setelah direalisasikan pembiayaannya maka Debitur (pengusaha batu bata) wajib membayar angsuran sesuai kesepakatan pembiayaan bersamaan dengan itu pihak BMT AS-salam akan melakukan pengawasan kepada nasabah (pengusaha batu bata) agar teratur dalam melakukan angsuran dan juga lebih ada motivsi untuk lebih maju. ${ }^{12}$

2. Proses Pembiayaan

${ }^{12}$ Muhsin. Wawancara.Kediri. 27 juli 2013

Website:http://jurnal.radenfatah.ac.id/index.php/ieconomics 
Pada proses pembiayaan ini ada kriteria dan syarat-syarat yang harus dipenuhi oleh pihak nasabah diantaranya melihat kelayakan nasabah dalam hal legalitas, karakter calon nasabah, usaha yang dijalankan layak apa tidak, ini semua akan di verifikasi oleh pihak pemasaran BMT yang kemudian disetujui atau tidaknya calon nasabah menerima pembiayaan.

3. Pencairan Pembiayaan

Perlu ditegaskan bahwa akad pembiayaan modal kerja bukanlah akad pinjam meminjam uang, tetapi merupakan akad jual beli, sehingga dalam prakteknya pihak BMT memberlakukan akad wakalah dalam jual beli murabahah. Yakni pihak BMT meminta nasabah untuk membeli barang yang dikehendaki oleh nasabah sesuai dengan kesepakatan awal. Dalam pembiayaan modal kerja ini barang yang dimaksud adalah bahan baku untuk keperluan usaha calon nasabah. Karena kedudukan nasabah dalam akad wakalah adalah sebagai wakil pihak BMT, maka setelah transaksi dengan supplier terjadi, secara tidak langsung barang yang dibeli tersebut adalah milik BMT. Oleh karena itu dokumen jual beli dan lain-lainnya diserahkan oleh nasabah kepada pihak BMT, baru setelah barang secara resmi menjadi milik BMT, maka dilakukan akad Murabahah antara pihak BMT dengan nasabah. Adapun keuntungan yang diambil oleh pihak BMT dalam transaksi murabahah ini adalah berupa selisih lebih antara harga perolehan dengan harga jual. Penetapan keuntungan tersebut bukan semata-mata ditetapkan atas kehendak pihak BMT secara personal, akan tetapi juga melibatkan nasabah untuk melakukan tawar menawar hingga tercapai kesepakatan bersama.

\section{B. Peranan pembiayaan murabahah di BMT As-salam cabang Ngreco Kandat Kediri terhadap peningkatan usaha batu bata di desa Ngreco Kandat Kediri}

Peranan BMT As-salam cabang Ngreco Kandat Kediri ini cukup vital di masyarakat Desa Ngreco dikarenakan hampir seluruh masyarakat adalah pengusaha batu bata, kesulitan pembiayaan dan jaminan yang terlalu tinggi pada lembaga keuangan lain mengakibatkan keberadaan BMT As-salam cabang Ngreco Kandat Kediriini sangat diminati oleh warga, hal ini Website:http://jurnal.radenfatah.ac.id/index.php/ieconomics 
disampaikan oleh Bapak Mulyani, beliau mengatakan,"karena proses dalam melayani nasabah sangat cepat, dan tidak rumit, saya sudah 2 tahun lebih mas menjadi nasabah di BMT as-salam dan saya termasuk nasabah paling awal menjadi nasabah beliau juga menuturkan bahwa memelih menjadi nasabah BMT As-salam karena lokasi BMT As-salam sangat dekat dengan rumah jadi apabila mengangsur pembiayaan lebih dekat tidak jauh-jauh dan sangat berbeda dengan BPRS Artha Pamenang yang penarikan bunga sangat tinggi dan tenggang waktu hanya satu minggu setelah jatuh tempo.” 13

Seperti dikatakan Bapak Parwoto,"ya awalnya tidak tahu mas, apa BMT itu, pada waktu pertama BMT As-salam di Ngreco ini tidak langsung berdiri seperti sekarang, tetapi mereka ikut rumah sebelahnya yang juga rumah milik bapak Toyyib, disitulah dulunya kantor mereka, kemudian mereka mengumpulkan semua bapak-bapak desa Ngreco di masjid jami' Ngreco terutama mereka yang pengusaha batu - bata, dengan bantuan bapak Toyyib selaku karyawan BMT As-salam akhirnya hampir semua warga Ngreco menjadi nasabahnya, termasuk saya alhamdulillah mas. Tentang pertanyaannya mas, BMT As-salam ini karyawanya sangat ramah dan sangat mengerti keadaan orang miskin, mereka memberikan tenggang waktu setelah jatuh tempo pembayaran angsuran. Selain itu penciran dana sangat cepat tidak berbelit-belit dengan persyaratan sangat berbeda dengan BPRS Artha Pamenang."14

Wawancara di atas didukung dengan data yang diambil dari pihak BMT As-salam di Desa Ngreco dengan berbagai jenis usaha dengan fokus pada pengusaha batu bata, BMT As-salam cabang Ngreco Kandat Kediri menjadi tempat yang menarik perhatian bagi masyarakat desa Ngreco khususnya pengusaha batu bata untuk mengambil pembiayaan atas usahanya.

Peranan BMT As-salam cabang Ngreco Kandat Kediri dalam membantu masyarakat untuk menjalankan usahanya, menurut mereka perkembangan usaha yang mereka jalankan ini adalah karena pertolongan dari Allah dengan

${ }^{13}$ Mulyani. Wawancara. Kandat. 9 Mei 2014

Website:http://jurnal.radenfatah.ac.id/index.php/ieconomics 
melalui pembiayaan murabahah dari BMT As-salam cabang Ngreco Kandat Kediri, walau memang tidak ada tolak ukur untuk mengukur seberapa besar manfaat dan peranan pembiayaan murabahah yang mereka rasakan, tetapi dari jawaban para nasabah yang ditemui, mereka tidak memungkiri bahwa peranan pembiayaan murabahah ini sangat membantu terhadap usaha mereka.Seperti yang dikutip dari komentar. Bapak Rajin / Istri Bapak Rajin, "Saya memang mengambil pembiayaan di Pak Toyib (BMT Assalam), manfaat yang saya rasakan sangat banyak mas, dari pembiayaan tersebut, ekonomi saya sangat terbantu, dan usaha saya bisa agak terbantu, dulu tidak punya motor sekarang bisa membeli motor walaupun bekas, dulu saya hanya mengandalkan buruh tani. Setelah dapat pembiayaan dari Pak Toyib (BMT As-salam) saya punya modal untuk usaha batu bata sendiri dan alhamdulillah sampai sekarang saya masih menggunakan pembiayaan tersebut". 15

Demikian pula nasabah yang lain seperti di kutip dari komentar Bapak Ismail. "Alhamdulillah, saya mengambil pembiayaan di BMT As-salam, dari pembiayaan tersebut saya sangat terbantu apalagi saya sekarang sedang masa-masa membangun rumah, hasil penjualan batu bata ini sebagian saya angsur sebagian untuk membangun rumah dan baik itu usaha batu bata ataupun pembangunan rumah saya tetap berjalan dan jika kekurangan modal saya juga masih pinjam ke BMT As-salam itu". ${ }^{16}$

Demikian pernyataan dari bapak mulyani,"Menurut saya dengan adanya BMT AS-salam itu, usaha saya lebih maju dan tenang, tenangnya begini mas, dulu jika saya usaha batu bata ini sering mengalami kemacetan dana atau modal karena sampean juga tahu bahwa batu bata harganya tidak stabil ditambah tidak langsung terjual batu tersebut, perlu waktu untuk ada yang menawar, makanya jika ada modal baik usaha maupun ekonomi lebih gampang, alhamdulillah mas, saya juga bisa mensekolahkan anak saya ke

\footnotetext{
${ }^{15}$ Rajin. Wawancara. Kandat. 11 Mei 2014

${ }^{16}$ Ismail. Wawancara. Kandat. 11 Mei 2014
}

Website:http://jurnal.radenfatah.ac.id/index.php/ieconomics 
jenjang perkuliahan, motor saya sekarang dulunya 1 sekarang 3 alhamdulillah". ${ }^{17}$

Sejak berdiri tahun 2008 di Ngreco sampai tahun 2014, BMT As-salam cabang Ngreco Kandat Kediri ini selalu mengalami peningkatan jumlah nasabah pada pengusaha batu bata yang memang menjadi prioritas utama mancari nasabah

\section{Peningkatan usaha batu bata di desa Ngreco Kandat Kediri setelah mendapatkan pembiayaan murabahah di BMT As-salam cabang Ngreco Kandat Kediri}

Peningkatan usaha para pengusaha batu bata ini adalah hasil dari penerapan dan peranan pembiayaan murabahah di BMT As-salam cabang Ngreco Kandat Kediridan kerjasama dengan masyarakat Ngreco. Jika penerapan dan peranan ini sesuai rencana dan berjalan dengan baik, hasilnya usaha para pengusaha batu bata juga akan meningkat. Dengan begitu, antara BMT As-salam cabang Ngreco Kandat Kediridengan pengusaha batu bata akan saling membutuhkan. Pengusaha batu bata membutuhkan modal untuk usaha sedangkan BMT As-salam cabang Ngreco Kandat Kediri membutuhkan nasabah untuk memutar aliran dana. untuk mengetahui peningkatan usaha batu bata. Untuk membuktikan peningkatan tersebut,perlu adanya data tentang sebelum dan sesudah mengambil pembiayaan murabahah di BMT As-salam cabang Ngreco Kandat Kediri.

\section{KESIMPULAN}

Dari hasil Interview, observasi dan dokumentasi, semua sepakat dan mengakui bahwa BMT As-salam cabang Ngreco Kandat Kediri memiliki peranan yang lebih dari segi pembiayaan bagi masyarakat Desa Ngreco khususnya pengusaha batu bata, hal ini bisa dilihat dari wawancara para nasabah seperti bapak Mulyani, Parwoto, Ismail, Rajin, Hariono, Dardiri, Marwi. dan dari segi peningkatan usaha masyarakat sebelum dan sesudah menjadi nasabah BMT Assalam cabang Ngreco Kandat Kediri, terbukti BMT As-salam cabang Ngreco Kandat Kedirimemberikan dampak yang siknifikan bagi para pengusaha

${ }^{17}$ Mulyani. Wawancara. Kandat. 11 Mei 2014

Website:http://jurnal.radenfatah.ac.id/index.php/ieconomics 
khususnya pengusaha batu bata, sesuai dengan pendapat Daud, ada tiga yang harus difahami untuk menjadi kemaslahatan umat yang pertama : penyucian jiwa, agar muslim selalu menjadi sumber kebaikan bagi masyarakat lingkungannya, tang kedua : menegakkan keadilan dalam masyarakat Islam, yang ketiga : yang merupakan tujuan puncak yaitu mencapai kemashatan yang Fallah atau maslahat dunia dan akhirat. ${ }^{18}$ Karena itu BMT As-salam cabang Ngreco Kandat Kediri selalu mendapat dukungan dari masyasrakat dan juga para nasabah untuk terus maju dan mengembangkan jaringan BMT baik kepada masyarakat atau klien (kerjasama) yang lebih luas.

\section{DAFTAR PUSTAKA}

Agil Bahsoan, Maslahah sebagai Maqoshid Al Syariah(Tinjauan dalam perspektif Ekonomi Islam), Inovasi No. 8, Vol. 1, Maret 2011, ISSN 16939034

Antonio, Muhammad Syafi'i, Bank Syari'ah: Dari Teori Ke Praktek, Jakarta: Gema Insani Press, 2001.

Bagya Agung Prabowo, Konsep Akad murabahah pada perbankan syariah(analisa kritis terhadap konsep Akad Murabahah di Indonesia dan Malaysia), Jurnal Hukum No. 1, Vol. 16 Januari, 2009 : 106-126

Chapra, M, Umer, Towards a just monetary system Bibliolografi, terj Lukman Hakim, Yogyakarta: Dhana Bhakti Prima Yasa, 1997.

Departemen Agama RI, AL-Quran dan Terjemahnya AL-Jumanatul 'Ali, Bandung: CV Penerbit J-ART, 2004,

Franky S, Hetty K Tunjungsari, Mei Le, Dasar-Dasar Kewirausahaan:Teori dan Praktik, Jakarta Barat: Indeks, 2016.

Muhammad, Sistem dan Prosedur Operasional Bank Syariah, Yogyakarta: UII Press Yogyakarta,2008.

Soemitra, Andri, Bank dan Lembaga Keuangan Syariah, Jakarta: Kencana, 2016.

\footnotetext{
${ }^{18}$ Agil Bahsoan, Maslahah sebagai Maqoshid Al Syariah(Tinjauan dalam perspektif Ekonomi
} Islam), Inovasi No. 8, Vol. 1, Maret 2011, ISSN 1693-9034

Website:http://jurnal.radenfatah.ac.id/index.php/ieconomics 
I-Economics: A Research Journal on Islamic Economics ISSN 2548-5601, e-ISSN 2548-561X

Vol. 5. No 1. Juni 2019

Sudarsono, Heri, Bank dan Lembaga Keuangan Syari'ah, Deskrips dan Ilustrasi, Yogyakarta: Ekonisia, 2003.

Tim Esistensi, Pengembangan Lembaga Keuangan Syari'ah Bank Muamalat, Perbankan Syari'ah Perspektif Praktisi Muamalat Institut, 1992.

Tim penyusun, Pengembangan industri petrokimia di Indonesia, Jakarta: Indonesia chemichal industries club, 2001.

Website:http://jurnal.radenfatah.ac.id/index.php/ieconomics 